Canadian

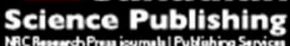

Applied Physiology, Nutrition, and Metabolism Physiologie appliquée, nutrition et métabolisme

\title{
Timing and pattern of post-exercise protein ingestion affects whole body protein balance in healthy children: a randomized trial
}

\begin{tabular}{|r|l|}
\hline Journal: & Applied Physiology, Nutrition, and Metabolism \\
\hline Manuscript ID & apnm-2017-0185.R1 \\
\hline Manuscript Type: & Article \\
\hline Date Submitted by the Author: & 19-Jun-2017 \\
\hline Complete List of Authors: & $\begin{array}{l}\text { Volterman, Kimberly; McMaster University, Childrens Exercise and Nutrition } \\
\text { Centre } \\
\text { Moore, Daniel; University of Toronto, Faculty of Kinesiology and Physical } \\
\text { Education } \\
\text { Breithaupt, Peter; McMaster University } \\
\text { Grathwohl, Dominik; Nestlé SA, Clinical Development Unit } \\
\text { Offord, Elizabeth; Nestle Research Center } \\
\text { Karagounis, Leonidas; Nestle Research Center } \\
\text { Timmons, Brian; McMaster University, }\end{array}$ \\
\hline Is the invited manuscript for \\
consideration in a Special \\
Issue? :
\end{tabular}$\quad \begin{aligned} & \text { Keyword: } \\
& \text { youth, growth < metabolism, exercise nutrition < exercise }\end{aligned}$


Timing and pattern of post-exercise protein ingestion affects whole body protein balance in healthy children: a randomized trial

Kimberly A. Volterman*1, Daniel R. Moore*², Peter Breithaupt ${ }^{1}$, Dominik Grathwohl ${ }^{3}$, Elizabeth A. Offord ${ }^{3}$, Leonidas G. Karagounis ${ }^{3}$, and Brian W. Timmons ${ }^{1}$

${ }^{1}$ Child Health \& Exercise Medicine Program, Department of Pediatrics, McMaster University, Hamilton, Canada; ${ }^{2}$ Faculty of Kinesiology and Physical Education, University of Toronto, Toronto, Canada; ${ }^{3}$ Department of Nutrition and Health Research, Nestle Research Centre, Lausanne, Switzerland

*These authors contributed equally to this work

Kimberly Volterman (k.volterman@utoronto.ca)

Faculty of Kinesiology and Physical Education, University of Toronto, 1280 Main Street West, Room 3N27G, Toronto, ON, M5S 2C9

Daniel Moore (dr.moore@utoronto.ca)

Faculty of Kinesiology and Physical Education, University of Toronto, 100 Devonshire Place, Room 426, Toronto, ON, M5S 2C9

Peter Breithaupt (pbrei083@gmail.com)

Faculty of Kinesiology and Physical Education, University of Toronto, 1280 Main Street West, Room 3N27G, Toronto, ON, M5S 2C9

Dominik Grathwohl (dominik.grathwohl@rdls.nestle.com)

Clinical Development Unit, Nestle Research Centre, 1000 Lausanne 26, Switzerland

Elizabeth Offord (elizabeth.offord-cavin@rdls.nestle.com)

Department of Nutrition and Health Research, Nestle Research Centre, 1000 Lausanne 26, Switzerland

Leonidas Karagounis (Leonidas.Karagounis@rdls.nestle.com)

Department of Nutrition and Health Research, Nestle Research Centre, 1000 Lausanne 26, Switzerland

Brian Timmons (timmonbw@mcmaster.ca)

Department of Pediatrics, McMaster University, 1280 Main Street West, Room 3N27G, Hamilton, ON, L8S 4K1

Running Title: Timing of post-exercise protein in children 


\section{Current Address for Correspondence:}

Daniel R. Moore

Faculty of Kinesiology and Physical Education

University of Toronto

Toronto, ON. Canada

M5S 2C9

Tel: 416-946-4088

Email: dr.moore@utoronto.ca 


\begin{abstract}
The dose and timing of post-exercise protein ingestion can influence WBPB in adults, although comparable data from children are scarce. This study investigated how protein intake (both, amount and distribution) post-exercise can affect WBPB in physically active children. Thirty-five children (26 males; 9-13 years old) underwent a 5-d adaptation diet consuming $0.95 \mathrm{~g}$ protein $\cdot \mathrm{kg}^{-1} \cdot \mathrm{d}^{-1}$. To assess whole body protein kinetics over $6 \mathrm{~h}$ and $24 \mathrm{~h}$ of recovery, participants consumed $2 \mathrm{mg} \cdot \mathrm{kg}^{-1}\left[{ }^{15} \mathrm{~N}\right]$ glycine before performing $3 \times 20$-min of variable intensity cycling. Fifteen grams of protein was distributed across 2 isoenergetic carbohydrate-containing beverages (i.e. 15 and 240 min post-exercise) containing reciprocal amounts of protein [i.e., $0+15 \mathrm{~g}, 5+$ $10 \mathrm{~g}, 10+5 \mathrm{~g}$ and $15+0 \mathrm{~g}$ for Groups A-D, respectively]. Over the $6-\mathrm{h}$ that included the exercise bout and the first beverage at 15 min post-exercise, WBPB (i.e. synthesis - breakdown) demonstrated a linear increase of $0.647 \mathrm{~g} \cdot \mathrm{kg}^{-1} \cdot \mathrm{d}^{-1}$ per $1 \mathrm{~g}$ protein intake $(P<0.001)$. Over $24 \mathrm{~h}$, robust regression revealed that WBPB was best modeled by a parabola $(P<0.05)$, suggesting that a maximum in WBPB was achieved between groups B and C. . In conclusion, despite a dose-response early in recovery, a periodized protein intake with multiple smaller doses after physical activity may be more beneficial than a single bolus dose in promoting daily WBPB in healthy active children.
\end{abstract}

Key Words: protein metabolism, protein distribution, physical activity, adolescents, youth, growth, muscle, lean body mass 


\section{Introduction}

Two important contributors to physical growth and development during childhood are proper nutrition (Rodriguez 2005) and physical activity (Tobias et al. 2007). Provided energy needs are met, dietary protein, in particular, plays an important role in physical growth and development in children as it provides the substrates to support the remodeling and growth of lean tissues such as muscle and bone (Rodriguez 2005). Normal somatic growth in children is generally associated with more rapid rates of tissue remodeling and whole body protein turnover (i.e. protein synthesis and protein breakdown) than in adults (Duggleby and Waterlow 2005). In addition, physically active children have been reported to display a greater lean mass development than their sedentary peers (Baxter-Jones et al. 2008), which would ultimately be supported by adequate energy and protein intake and underpinned by enhancements in whole body net protein balance (WBPB; the algebraic difference between synthesis and breakdown). Despite the importance of dietary protein to support normal growth in active youth and its wellknown ability to enhance exercise-induced increases in muscle and whole body protein balance in adults (Rasmussen et al. 2000, Levenhagen et al. 2002, Moore et al. 2009), we currently know very little about the potential interacting effects of exercise and protein ingestion during childhood.

We have recently demonstrated that post-exercise protein ingestion enhances whole body anabolism in healthy, active children (Volterman et al. 2014, 2017, Moore et al. 2014). Specifically, we showed that post-exercise protein ingestion induced a dose-dependent increase in WBPB (determined by oral $\left[{ }^{15} \mathrm{~N}\right]$ glycine) over $9 \mathrm{~h}$ following a single bout of cycling exercise (Moore et al. 2014), which we recently confirmed with a primed constant $\left[{ }^{13} \mathrm{C}\right]$ leucine infusion over a 3-h recovery period (Volterman et al. 2017). Despite the early dose-response, an intake of 
$\sim 13 \mathrm{~g}$ (or $\sim 0.32 \mathrm{~g} \cdot \mathrm{kg}^{-1}$ ) of protein immediately following exercise was required to maintain a positive WBPB over an entire 24-h period. However, the post-exercise protein intake in our previous study was additive to the daily intake, which resulted in differences in 24-h protein ingestion (Moore et al. 2014). As such, it is not clear if there was a potential synergy between exercise and protein ingestion or if the greater WBPB observed following the consumption of $\sim 13 \mathrm{~g}$ (but not $\sim 7$ or $0 \mathrm{~g}$ ) of protein was merely a reflection of the greater protein intake (i.e. by $\sim 0.32 \mathrm{~g} \cdot \mathrm{kg}^{-1}$ ) over the entire 24-h period (Boisseau et al. 2005). Moreover, the relative importance of consuming protein immediately after exercise versus at any point throughout the day could not be delineated from this study. Therefore, while recent studies have demonstrated that consuming protein after exercise in children may enhance WBPB over 9 to $24 \mathrm{~h}$ of recovery (Volterman et al. 2014, Moore et al. 2014), the importance of the post-exercise time period per $s e$ for protein consumption requires further study.

It is well-known in adults that protein ingestion is required to support maximal rates of protein synthesis and to induce anabolism after exercise (Tipton and Phillips 2013). The importance of protein ingestion during this immediate post-exercise period may be supported by the observation that muscle and whole body anabolism is attenuated when protein ingestions is delayed by up to $3 \mathrm{~h}$ after endurance exercise (Levenhagen et al. 2001), which may be similar to the exercise modality that children typically engage in (Faucette et al. 1995). In contrast, although the increase in muscle protein synthesis and net balance with post-exercise amino acid ingestion is additive to the $24 \mathrm{~h}$ response (Tipton et al. 2003), muscle hypertrophy (i.e. adult "growth") with resistance training is not consistently greater with protein ingestion immediately before/after exercise as compared to at other times throughout the day (Schoenfeld et al. 2013). This may be due to the ability of resistance exercise to enhance muscle anabolism for up to $24 \mathrm{~h}$ 
(Rasmussen et al. 2000, Burd et al. 2011). Recent acute studies have demonstrated that repeated ingestion of moderate (i.e. $20 \mathrm{~g}$ or $\sim 0.25 \mathrm{~g} \cdot \mathrm{kg}^{-1}$ in adults) protein doses may be optimal to support post-exercise muscle remodeling and WBPB over a prolonged (i.e. 12-h) recovery period (Moore et al. 2012, Areta et al. 2013). Thus, the pattern and not just the timing of protein intake outside of the early recovery period may be as (if not more) important to enhance net "growth" in exercising adults. We recently demonstrated that whole body leucine balance over $3 \mathrm{~h}$ of recovery increases in a dose-dependent manner in healthy children (Volterman et al. 2017). Therefore, as a secondary objective to our previous study (Volterman et al. 2017), we examined whether the timing (i.e., immediate vs. delayed) and distribution (i.e., single or repeated doses) of protein intake in relation to an acute bout of exercise influenced WBPB and nitrogen balance $\left(\mathrm{N}_{\mathrm{BAL}}\right)$ in healthy, active children consuming isonitrogenous diets.

\section{Materials and methods}

Participants. The present study is part of a separate study that investigated the effects of an acute single meal intake on whole body $\operatorname{Leu}_{\mathrm{BAL}}$ and, therefore, involved the same participants (as previously described (Volterman et al. 2017)). However, compared to the previous study that investigated the effect of a single beverage over a 3 -h post-exercise recovery period, the present study aimed to determine as a secondary outcome if the pattern of single protein intakes influenced whole body protein metabolism over more prolonged recovery periods when provided within isonitrogenous diets. Briefly, 36 children (26 males, 10 females) volunteered to participate in the study; one female participant withdrew from the study prior to completion due to a refusal to eat the required controlled study diet. All participants were healthy and recreationally active as determined by medical and activity questionnaire. Additional inclusion 
criteria required participants to be free of any existing medical condition, between the ages of 9 to 13 years, within 2 years from peak height velocity (YPHV), and have a minimum aerobic fitness of $35 \mathrm{ml} \cdot \mathrm{kg}^{-1} \cdot \mathrm{min}^{-1}$ as assessed by the McMaster All-Out Progressive Continuous Cycling Protocol (see below). Participants were excluded based on the following criteria: current use of medication, food allergy to milk proteins (e.g., whey or casein), and current participation or having participated in another nutritional-clinical trial within 2 months of the current study. This study was approved by the Faculty of Health Sciences/Hamilton Health Sciences Research Ethics Board. Each participant provided written informed assent and written informed consent was obtained from each parent prior to enrolment in the study.

General overview. Participants were enrolled in the study for a total duration of $\sim 3$ weeks whereby they reported to the laboratory on 3 separate occasions: a preliminary visit, a familiarization visit, and an exercise intervention visit. Participants were first provided with a 5day energy and macronutrient-matched controlled diet to allow their body to adapt to a protein intake of $0.95 \mathrm{~g}$ protein $\cdot \mathrm{kg}^{-1} \cdot \mathrm{d}^{-1}$ (the DRI for protein (Institute of Medicine 2002)). Following this adaptation phase, participants completed the intervention phase. The intervention visits were conducted in a randomized, double-blind, parallel four group design. During the exercise intervention visit, participants continued to consume the controlled diet but also performed a bout of exercise in the morning. Participants orally ingested an isoenergetic bovine skim milkbased protein and carbohydrate (sucrose) beverage containing a variable amount of protein immediately after exercise. A second protein beverage was consumed $4 \mathrm{~h}$ after exercise and contained a reciprocal amount of protein to a total of $15 \mathrm{~g}$ of protein across both beverages (see below for details). Participants ingested an oral $\left[{ }^{15} \mathrm{~N}\right]$ glycine tracer the morning of the exercise intervention day and collected all urine over the subsequent 6-h and 24-h periods to measure 
protein kinetics over $6 \mathrm{~h}$ and $24 \mathrm{~h}$, and $\mathrm{N}_{\mathrm{BAL}}$ over $24 \mathrm{~h}$. The 6-h period was included to assess changes in protein kinetics after the ingestion of a single beverage, whereas the 24-h period provided estimates over an entire day (i.e. 2 beverages with the controlled diet).

Preliminary visit. Participants completed a preliminary session during which height (Harpenden wall-mounted Stadiometer), body mass (BWB-800, Tanita Corp., Japan), percent body fat (\% BF) and lean body mass (InBody520 bioelectrical impedance analyzer; Biospace Co., California, USA for both), body mass index (BMI), chronological age and maturity offset were determined. Maturity offset was calculated as YPHV (Mirwald et al. 2002). To measure aerobic fitness, peak oxygen uptake $\left(\mathrm{VO}_{2 \text { peak }}\right)$ was then assessed on a cycle ergometer (Lode Corival, The Netherlands), as previously described (Timmons et al. 2006). Participants performed each of their subsequent exercise sessions on the same cycle ergometer as their aerobic fitness test. Physical characteristics of the participants are described elsewhere (Volterman et al. 2017).

Familiarization visit. The purpose of this visit was to: 1) determine individual resting metabolic rate (RMR); 2) familiarize the participants with the exercise protocol and equipment; 3) confirm appropriate exercise intensities; and 4) ensure participants could successfully complete the exercise. Participants reported to the lab $(\sim 07: 30 \mathrm{~h})$ in an overnight fasted condition. Participants then rested in a quiet room for 10-min while individual RMR was assessed using a calibrated metabolic cart (Vmax 29, SensorMedics, Yorba Linda, CA, U.S.A.) and an appropriately sized canopy. Participants then consumed a small liquid meal (Boost Meal Replacement, Nestle Canada Inc., North York, Ont. Canada) as a light breakfast as well as a minimum of $5 \mathrm{ml} \cdot \mathrm{kg}^{-1}$ of water and rested comfortably for $1 \mathrm{~h}$ prior to beginning the exercise protocol (using the same exercise as during the exercise intervention visit, described below). To 
characterize habitual physical activity levels, participants were then asked to wear an accelerometer (ActiGraph GT1M or GT3X; AtiGraph, Pensacola, Florida) for 3 days. Data were analyzed using a custom-made Microsoft Excel-based Visual Basic data reduction program (Microsoft Corp, Redmond, Washington) to assess total and moderate-to-vigorous physical activity (MVPA) levels, as previously reported (Obeid et al. 2014) using the cut points developed by Evenson et al. (Evenson et al. 2008).

Exercise intervention visit. For an overview of the exercise intervention visit, see Figure 1. Participants reported to the laboratory $(\sim 07: 30 \mathrm{~h})$ after an overnight fast and provided a spot urine sample prior to voiding their bladders. Following the spot urine sample, participants consumed a small breakfast consisting of $\sim 24 \%$ and $\sim 22 \%$ of total daily energy and protein intake (see below for details), respectively. In addition, at least $5 \mathrm{ml} \cdot \mathrm{kg}^{-1}$ body weight of water was consumed that included $2 \mathrm{mg} \cdot \mathrm{kg}^{-1}$ body weight of $\left[{ }^{15} \mathrm{~N}\right]$ glycine to determine whole body protein kinetics (see below for details). Participants then began the exercise protocol, which consisted of 3 blocks of 20-min of exercise separated by 5-min of rest between blocks. Each exercise block consisted of 20 -min of cycling at $50 \%$ of their previously determined $\mathrm{VO}_{2 \text { peak}}$, with 10 -s sprints at the workload corresponding to $100 \% \mathrm{VO}_{2 \text { peak }}$ interspersed every 110 -s between min 5 and 15 of exercise. This variable intensity exercise was selected to more closely model the intermittent and sporadic nature of child play (Bailey et al. 1995, Welk et al. 2000, Trost 2001, Epstein et al. 2001). Body weight was measured prior to exercise and during the rest period between exercise blocks and participants were provided with water to consume ad libitum to ensure adequate hydration (i.e., $100 \mathrm{~g}$ body weight change $=100 \mathrm{~mL}$ fluid).

Upon completing the exercise, participants were provided with the first assigned experimental beverage were instructed to consume it within 5-min. Participants then rested 
comfortably in a seated position in the lab for $225 \mathrm{~min}$ (i.e. $240 \mathrm{~min}$ after exercise) and collected all urine up to this point, which served as the 6-h recovery period. Participants then consumed the second experimental beverage containing the reciprocal amount of protein (see below for details) within 5-min. Participants were provided with a pre-packaged controlled diet and were permitted to return home. Participants were instructed to maintain habitual levels of physical activity and collected all urine until the following morning (see below for details), which served as the 24-h recovery period.

Beverages. All beverages were prepared by dissolving the powders provided by Nestec Ltd containing different ratios of carbohydrate and protein. Beverages were reconstituted in deionized water to a fixed volume of $250 \mathrm{~mL}$ the evening prior to the trials and kept chilled at 4 ${ }^{\circ} \mathrm{C}$ until ingestion. The first beverage (15 min post-exercise) contained $0 \mathrm{~g}$ (Group A), $5 \mathrm{~g}$ (Group B), 10 g (Group C), or 15 g (Group D) of bovine skim milk protein (subsequently containing both whey and casein protein fractions in a ratio $\sim 1: 4$, respectively) with variable carbohydrate (sucrose) to provide $(\sim 140 \mathrm{kcal})$. The second beverage (240 min post-exercise) provided a reciprocal amount of protein (i.e. $15 \mathrm{~g}, 10 \mathrm{~g}, 5 \mathrm{~g}$ and $0 \mathrm{~g}$ protein in Groups A-D, respectively) and carbohydrates to the first beverage. Therefore, all groups received a total of $15 \mathrm{~g}$ of protein and $55 \mathrm{~g}$ of carbohydrate $(\sim 280 \mathrm{kcal})$ over the 240 -min post-exercise period.

Controlled diet. During the adaptation and intervention phases of the trial, participants were provided with a controlled diet providing $0.95 \mathrm{~g}$ protein $\cdot \mathrm{kg}^{-1} \cdot \mathrm{d}^{-1}$. Energy intake was calculated using the habitual activity levels of each participant (measured by accelerometer) and was varied throughout the trial to ensure energy balance was approximately neutral. For dietary compliance, all food was provided to the participants at their home in prepackaged containers for each day of the study and participants/guardians confirmed the ingestion of each food item 
during the day by selecting the item from a provided checklist upon eating. Participants/guardians were instructed that no food or drink (except water) other than what was provided was to be ingested during the controlled diet period. All food containers were kept and returned to the laboratory to ensure consumption, and any food item that was uneaten during the controlled diet period (and subsequently returned) was recorded and its nitrogen content was subtracted from the daily nitrogen intake.

Urine samples. A fasted spot urine sample was collected and subsequently analyzed for background $\left[{ }^{15} \mathrm{~N}\right]$ urea and ammonia enrichment. Any urine produced while in the laboratory up to the second beverage (i.e., $240 \mathrm{~min}$ of recovery) was collected into a labeled container and pooled. Three $3 \mathrm{ml}$ aliquots were subsequently frozen at $-80^{\circ} \mathrm{C}$ prior to the determination of metabolite concentrations and isotopic enrichment for the 6-h recovery period. After storing the 6-h aliquots, the remaining 6-h urine was stored at $4^{\circ} \mathrm{C}$ until the following day. Upon leaving the laboratory, each participant was provided with a $4 \mathrm{~L}$ container to collect all urine produced during the remainder of the day until the first urination the following morning (inclusive), and instructed to store it at $4{ }^{\circ} \mathrm{C}$; this urine was then pooled with the urine collected during the 6-h inlab period and three $3 \mathrm{ml}$ aliquots were frozen at $-80^{\circ} \mathrm{C}$ prior to analysis for the $24-\mathrm{h}$ recovery period. The concentration of the major nitrogen-containing metabolites urea and creatinine were determined colorimetrically by commercially available kits (Quantichrom, Bioassay Systems, USA), as an estimate of urinary nitrogen excretion $\left(\mathrm{N}_{\mathrm{EX}}\right)$. Total nitrogen intake $\left(\mathrm{N}_{\mathrm{IN}}\right)$ and $\mathrm{N}_{\mathrm{EX}}$ [using previously published values of fecal and miscellaneous nitrogen losses for children consuming a $1.2 \mathrm{~g}$ protein $\cdot \mathrm{kg}^{-1} \cdot \mathrm{d}^{-1}$ diet (Gattas et al. 1990)] were used to calculate nitrogen balance $\left(\mathrm{N}_{\mathrm{BAL}}=\mathrm{N}_{\mathrm{IN}}-\mathrm{N}_{\mathrm{EX}}\right)$ over the 24-h recovery period. In addition, the $\left[{ }^{15} \mathrm{~N}\right]$-enrichments (i.e. ratio of tracer:trace; t:Tr) of urinary ammonia (baseline, $6 \mathrm{~h}$, and $24 \mathrm{~h}$ ) and urea (baseline 
and $24 \mathrm{~h}$ ) were determined in duplicate by isotope ratio mass spectrometry by Metabolic Solutions Incorporated (Nashua, New Hampshire, USA) to determine whole body nitrogen turnover $(\mathrm{Q})$, protein synthesis $(\mathrm{S})$, protein breakdown (B) and net protein balance (WBPB), as previously described (Moore et al. 2014). Protein kinetics over $6 \mathrm{~h}$ were assessed using the $\left[{ }^{15} \mathrm{~N}\right]$ ammonia end-product approach whereas 24 -h protein kinetics were calculated using both the $\left[{ }^{15} \mathrm{~N}\right]$ ammonia end-product as well as the harmonic mean of $\left[{ }^{15} \mathrm{~N}\right]$ ammonia and $\left[{ }^{15} \mathrm{~N}\right]$ urea end-product enrichment. This approach was taken as ammonia nitrogen turnover is more rapid and therefore can be used to determine Q over both short (6-9h) and long (24h) measurement periods (Grove and Jackson 1995). In contrast, urea nitrogen turnover requires greater durations (up to 24h) for adequate tracer excretion (Grove and Jackson 1995). Given the differences in rates of nitrogen turnover in ammonia and urea body pools, and it has been suggested that the harmonic mean may provide a more robust estimate of Q over a $24 \mathrm{~h}$ period with a single oral tracer dose (Fern et al. 1985). Thus, while providing qualitatively similar estimates over $24 \mathrm{~h}$ there may be subtle quantitative differences between $24 \mathrm{~h}$ rates of Q (and thus S and B) when utilizing urinary ammonia enrichment only or the harmonic mean of ammonia and urea (Grove and Jackson 1995).

Statistics. Outliers were visually identified, and we thus used robust regression analyses to take the outliers into account. Outcome variables which were apparently not affected by outliers were analyzed by classical regression techniques. Therefore, group differences in the controlled diet, habitual physical activity, and the diet on the exercise intervention day were examined using a one-way ANOVA (group). Whole body Q, S, B and WBPB measured over 6 $\mathrm{h}$ and over $24 \mathrm{~h}$ were analyzed by robust regression (lmrob, library robustbase in $\mathrm{R}$ ), where protein intake was used as the explanatory variable. To determine if 6-h WBPB, 24-h WBPB and 
24-h $\mathrm{N}_{\mathrm{BAL}}$ were significantly different from zero, a one sample $t$-test was performed for each group. All statistical analyses aside from the robust regressions were performed using SPSS Statistics Version 20.0. Statistical significance was set at $P \leq 0.05$ and all data are expressed as mean \pm SD unless otherwise indicated.

\section{Results}

Habitual physical activity. Total habitual physical activity from the 3-day accelerometer was $225.4 \pm 47.0,212.3 \pm 69.0,187.3 \pm 68.5$, and $206.8 \pm 57.3 \mathrm{~min} \cdot \mathrm{d}^{-1}$ for Groups A-D, respectively. Total habitual physical activity did not differ between groups $(P=0.74)$. Habitual MVPA from the 3-day accelerometer was $74.0 \pm 30.9,71.5 \pm 28.4,47.2 \pm 25.3,58.7 \pm 24.5$ $\min \cdot \mathrm{d}^{-1}$ for Groups A-D, respectively. There were no group differences for MVPA $(P=0.27)$.

Macronutrient intake. The macronutrient intake across the 5-day adaptation period did not differ between experimental groups, and has been presented previously (Volterman et al. 2017). There were no group differences with respect to their diet on the intervention day (see Table 1).

Beverage protein intake. The relative protein intake for beverage 1 was $0,0.12 \pm 0.02$, $0.22 \pm 0.04$, and $0.33 \pm 0.08 \mathrm{~g}$ protein $\cdot \mathrm{kg}^{-1}$ for Groups A-D, respectively. The relative protein intake for beverage 2 was $0.37 \pm 0.08,0.24 \pm 0.05,0.11 \pm 0.02$, and $0 \mathrm{~g} \cdot \mathrm{kg}^{-1}$ for Groups A-D, respectively. Total protein intake from both beverages was $0.35 \pm 0.07 \mathrm{~g} \cdot \mathrm{kg}^{-1}$ with no significant difference between groups $(P=0.56)$.

Whole body 6-h protein metabolism by I ${ }^{15}$ Jammonia end product enrichment. Whole body Q, S, and B calculated by the $\left[{ }^{15} \mathrm{~N}\right]$ ammonia end product enrichment are presented in Table 2. Analysis of $\mathrm{Q}, \mathrm{S}$, and $\mathrm{B}$ by robust regression revealed no significant relationship across 
groups. Analysis of the 6-h WBPB by robust regression is presented in Figure 2. A significant linear term suggest a dose response with incremental protein intakes $(\Delta$ between groups $=0.647$ $\mathrm{mg} / \mathrm{kg} / \mathrm{h}, \mathrm{CI}: 0.158$ to $4.09 \mathrm{mg} / \mathrm{kg} / \mathrm{h}, \mathrm{p}=0.0003)$. At $6 \mathrm{~h}, \mathrm{WBPB}$ was greater than zero for Groups $\mathrm{C}$ and $\mathrm{D}(P<0.01$ for both), not different from zero in Group B $(P=0.40)$, and tended to be less than zero for Group A $(P=0.09)$.

Whole body 24-h protein metabolism by harmonic mean of $I^{15}$ NJammonia and $I^{15}$ NJurea end product enrichment. Whole body Q, S, and B calculated by the harmonic mean of urinary $\left[{ }^{15} \mathrm{~N}\right]$ ammonia and $\left[{ }^{15} \mathrm{~N}\right]$ urea are presented in Table 3. Analysis of Q, S, and B by robust regression revealed no significant relationship across groups.Analysis of WBPB over $24 \mathrm{~h}$ by robust regression is presented in Figure 3. A rise and fall of WBPB over $24 \mathrm{~h}$ that was dependent on the distribution of protein post-exercise was observed and could subsequently be modelled by a parabola which in of itself was significant $(p=0.045)$. Moreover, the parabola suggests a maximum in WBPB is achieved by spreading the doses between groups B and C. Therefore, the quadratic curvature suggests that multiple smaller feedings result in a greater WBPB than single feedings. Individual group means were not statistically significantly different from zero, although removal of outliers (see Figure 3) resulted in a tendency for WBPB to be greater than zero in Group B $(P=0.06)$.

Whole body 24-h $\boldsymbol{N}_{\boldsymbol{B A L}}$. At $24 \mathrm{~h}$, the median and interquartile ranges for $\mathrm{N}_{\mathrm{BAL}}$ separated by group were: Group A, -0.01 [-2.50, 2.27]; Group B, 1.47 [-0.65, 3.56]; Group C, 1.12 [-0.20, 2.23]; Group D, -0.10 [-4.41, 1.03]. 24-h $\mathrm{N}_{\mathrm{BAL}}$ was not significantly different from zero for Group A $(P=0.70)$, Group B $(P=0.90)$, or Group D $(P=0.28)$, but was greater than zero for Group C $(P=0.04)$. Removal of outliers resulted in $\mathrm{N}_{\mathrm{BAL}}$ being greater than zero for Group B ( $P$ $=0.04)$. 


\section{Discussion}

Similar to our previous work (Moore et al. 2014, Volterman et al. 2017), we demonstrate that WBPB displays an ingested protein dose-response during the early acute recovery period. However, the present study extends on our previous work by demonstrating that the pattern of protein ingestion and not just the absolute amount throughout the day can influence the extent of whole body net anabolism over an extended 24-h period. Specifically, the ingestion of two moderate (i.e. $5-10 \mathrm{~g}$ or $\sim 0.12-0.22 \mathrm{~g} \cdot \mathrm{kg}^{-1}$ ) bolus protein intakes generally supported a greater whole body net anabolism (i.e., WBPB) compared to a single $15 \mathrm{~g}\left(\sim 0.33 \mathrm{~g} \cdot \mathrm{kg}^{-1}\right)$ protein dose consumed either immediately or $4 \mathrm{~h}$ after exercise. These data generally support the emerging focus on multiple protein feedings throughout the day as a means to maximize post-exercise recovery in adults (Thomas et al. 2016).

During the acute 6-h exercise and recovery period, we demonstrated that the amount of ingested protein had no effect on whole body protein synthesis or protein breakdown, which is consistent with our previous research in children utilizing an identical oral tracer (Moore et al. 2014) and is ultimately related to the differences in protein intake within the first beverage. As we have speculated previously (Moore et al. 2014), this lack of effect on tracer-derived rates of protein turnover may be related in part to the sensitivity and/or time resolution of our oral tracer and/or to the relatively small differences in protein intake (i.e. $\sim 0.1-0.33 \mathrm{~g} \cdot \mathrm{kg}^{-1}$ ) between conditions. In potential support, we observed subtle differences in estimates of whole body protein synthesis but not protein breakdown over 3-h with a primed constant leucine infusion, which is likely related to its generally greater precision and time resolution compared to present oral tracer methodology (Volterman et al. 2017). Nevertheless, utilizing non-invasive 
methodology over longer recovery times, our studies (present and Moore et al. 2014) may alternatively suggest that the relatively high rates of protein synthesis and breakdown that are characteristic of growing children (Grove and Jackson 1995) may only need to be minimally (and perhaps unperceptively by current oral stable isotope methodology) altered before translating into potentially meaningful differences in net protein balance. This may be reflected in the dose-dependent increase in WBPB in the present study over $6 \mathrm{~h}$ (including a $2 \mathrm{~h}$ pre and during exercise period) that generally aligns with similar observations over $9 \mathrm{~h}$ of recovery (Moore et al. 2014). Although the linear dose-dependent differences in WBPB herein generally align with our recent characterization of whole body leucine balance (Volterman et al. 2017), we speculate that the present results would likely represent an overestimate of true net protein balance as the relatively short (i.e. $4 \mathrm{~h}$ ) postprandial period may have precluded the ability to capture the complete nitrogen excretion from the single protein ingestion. Nevertheless, similar to our previous observations (Volterman et al. 2014, Moore et al. 2014), as well as those in adults (Levenhagen et al. 2002), post-exercise protein ingestion over the acute $6 \mathrm{~h}$ exercise and recovery period enhances WBPB in active children.

There was no effect of timing or distribution of post-exercise protein intake on $24 \mathrm{~h}$ whole body protein synthesis or breakdown, which is consistent with our previous study over a similar duration (Moore et al. 2014). It is perhaps not altogether surprising that there were no differences between conditions for $24 \mathrm{~h}$ protein synthesis/breakdown given that both relative protein intake and total energy intake, which are the primary variables that would be expected to influence daily rates of protein turnover and nitrogen retention (Garlick et al. 1991), were similar between conditions across the 24-h period. Nevertheless, as suggested earlier even small differences in protein synthesis/breakdown could translate into differences in WBPB. Thus, 
despite similar daily protein intakes, WBPB in the present study differed between groups when the distribution of protein intake was manipulated. We have previously demonstrated that the consumption of $13 \mathrm{~g}\left(\sim 0.32 \mathrm{~g} \cdot \mathrm{kg}\right.$ body weight $\left.{ }^{-1}\right)$, but not $7 \mathrm{~g}\left(\sim 0.18 \mathrm{~g} \cdot \mathrm{kg}\right.$ body weight $\left.{ }^{-1}\right)$, of protein immediately following an acute bout of aerobic exercise was sufficient to induce a positive 24-h WBPB in healthy children (Moore et al. 2014). However, the main limitation with our previous study was that total daily protein intake was not controlled (Moore et al. 2014), which precluded our ability to determine if the greater WBPB was specifically resulting from the post-exercise consumption of $\sim 0.32 \mathrm{~g}$ protein $\cdot \mathrm{kg}$ body weight ${ }^{-1}$ independently of the higher daily protein intake. By providing all groups with an identical total protein content from the experimental beverages (i.e. $\sim 0.35 \mathrm{~g} \cdot \mathrm{kg}$ body weight ${ }^{-1}$ over $4 \mathrm{~h}$ after exercise) and total daily protein intake (i.e. $\sim 1.20 \mathrm{~g} \cdot \mathrm{kg}$ body weight ${ }^{-1} \cdot \mathrm{d}^{-1}$ ), the present study demonstrated that the timing and pattern of protein ingestion, and not just the total daily amount, can affect 24-h WBPB.

It has previously been predicted that protein deposition needs for healthy physical growth and development in 12 year-old children (male and female) is $\sim 0.04 \mathrm{~g} \cdot \mathrm{kg}$ body $\mathrm{weight}^{-1} \cdot \mathrm{d}^{-1}$ (World Health Organization et al. 2007), which is less than the positive protein balance observed in the two conditions (Groups B and C) that received repeated protein feedings in the postexercise period. This apparent discrepancy may be related in part to the practical difficulty in determining all routes of nitrogen loss in acute metabolic studies (Tomé and Bos 2000) and our reliance on urinary nitrogen excretion and predicted miscellaneous losses, which collectively may have led to a slight overestimation of the true net protein balance. However, the magnitude of differences between groups in the present study (i.e. means of -0.27 to $+0.22 \mathrm{~g} / \mathrm{kg} / \mathrm{d}$ ) is similar to the range in our previous study using identical methodology but with different daily protein intakes in active children (-0.03 to $+0.21 \mathrm{~g} / \mathrm{kg} / \mathrm{d})$ (Moore et al. 2014). Nevertheless, any potential 
systematic underestimation of nitrogen excretion would have been consistent across all conditions and would not invalidate our observation of a relatively greater WBPB with repeated protein feedings. In fact, the present observation that the pattern (and not just the quantity) of protein ingestion can influence nitrogen retention and WBPB is not without precedence in children (Barja et al. 1972) or in adults at rest (Leverton and Gram 1949) or after exercise (Moore et al. 2012).

In summary, our results are generally consistent with current recommendations in adults that frequent protein feedings after exercise may optimize post-exercise recovery (Thomas et al. 2016). Specifically, we demonstrate that a periodized protein intake with multiple smaller doses of 5-10 g of protein during post-exercise recovery may be more beneficial than a single bolus dose in promoting a daily net positive WBPB in healthy physically active children. Inasmuch as a positive net protein balance is a requisite for growth, our results may suggest that active children, who have greater lean mass than their sedentary peers (Baxter-Jones et al. 2008), may benefit from periodized protein ingestion that favours repeated moderate protein intakes during recovery from exercise. Future studies should determine whether the present acute response is additive to the normal daily net protein balance beyond a single 24 -h period as a means to support optimal growth and development with an active lifestyle.

\section{Conflicts of Interest and Source of Funding}

This research was supported by a research grant from Nestec Ltd. Some of the authors are (EAO, LGK) or were (DRM) employees of Nestec Ltd. The authors have no financial conflicts of interest to declare. 


\section{Acknowledgements}

The authors are grateful to each of the participants and their families for their dedication and hard work throughout the study. In addition, we would like to thank N. Persadie and L. Gillis for their help in preparing the controlled diet, G. Tomedi Leites and J. Obeid for their help in conducting the study and collecting samples. We would also like to thank D. Breuille for his input into the interpretation of the results. Some of the authors are (EAO, LGK) or were (DRM) employees of Nestec Ltd. The authors have no financial conflicts of interest to declare. This work was supported by a research grant from Nestec Ltd. 


\section{References}

Areta, J.L., Burke, L.M., Ross, M.L., Camera, D.M., West, D.W.D., Broad, E.M., Jeacocke, N.A., Moore, D.R., Stellingwerff, T., Phillips, S.M., Hawley, J.A., and Coffey, V.G. 2013. Timing and distribution of protein ingestion during prolonged recovery from resistance exercise alters myofibrillar protein synthesis. J. Physiol. 591(Pt 9): 2319-2331. doi:10.1113/jphysiol.2012.244897. PMID:23459753.

Bailey, R.C., Olson, J., Pepper, S.L., Porszasz, J., Barstow, T.J., and Cooper, D.M. 1995. The level and tempo of children's physical activities: an observational study. Med. Sci. Sports Exerc. 27(7): 1033-1041. PMID:7564970.

Barja, I., Araya, H., Muñoz, P., Vega, L., Arteaga, A., and Tagle, M.A. 1972. Effect of spacing protein intake on nitrogen balance in normal children. Am. J. Clin. Nutr. 25(5): 506-511. PMID:5063196.

Baxter-Jones, A.D.G., Eisenmann, J.C., Mirwald, R.L., Faulkner, R.A., and Bailey, D.A. 2008. The influence of physical activity on lean mass accrual during adolescence: a longitudinal analysis. J. Appl. Physiol. 105(2): 734-741. doi:10.1152/japplphysiol.00869.2007. PMID:18467546.

Boisseau, N., Persaud, C., Jackson, A.A., and Poortmans, J.R. 2005. Training does not affect protein turnover in pre- and early pubertal female gymnasts. Eur. J. Appl. Physiol. 94(3): 262-267. doi:10.1007/s00421-004-1264-5. PMID:15765242.

Burd, N.A., West, D.W.D., Moore, D.R., Atherton, P.J., Staples, A.W., Prior, T., Tang, J.E., Rennie, M.J., Baker, S.K., and Phillips, S.M. 2011. Enhanced amino acid sensitivity of myofibrillar protein synthesis persists for up to $24 \mathrm{~h}$ after resistance exercise in young men. J. Nutr. 141(4): 568-573. doi:10.3945/jn.110.135038. PMID:21289204.

Duggleby, S.L., and Waterlow, J.C. 2005. The end-product method of measuring whole-body protein turnover: a review of published results and a comparison with those obtained by leucine infusion. Br. J. Nutr. 94(2): 141-153. PMID:16115347.

Epstein, L.H., Paluch, R.A., Kalakanis, L.E., Goldfield, G.S., Cerny, F.J., and Roemmich, J.N. 2001. How much activity do youth get? A quantitative review of heart-rate measured activity. Pediatrics, 108(3): E44. PMID:11533362.

Evenson, K.R., Catellier, D.J., Gill, K., Ondrak, K.S., and McMurray, R.G. 2008. Calibration of two objective measures of physical activity for children. J. Sports Sci. 26(14): 15571565. doi:10.1080/02640410802334196. PMID:18949660.

Faucette, N., Sallis, J.F., McKenzie, T., Alcaraz, J., Kolody, B., and Nugent, P. 1995. Comparison of fourth grade students' out-of-school physical activity levels and choices by gender: project SPARK. J. Health Educ. 26(Suppl 2): S82-S90.

Fern, E.B., Garlick, P.J., and Waterlow, J.C. 1985. The concept of the single body pool of metabolic nitrogen in determining the rate of whole-body nitrogen turnover. Hum. Nutr. Clin. Nutr. 39(2): 85-99. PMID:3894301.

Garlick, P.J., McNurlan, M.A., and Ballmer, P.E. 1991. Influence of dietary protein intake on whole-body protein turnover in humans. Diabetes Care, 14(12): 1189-1198. PMID:1773704.

Grove, G., and Jackson, A.A. 1995. Measurement of protein turnover in normal man using the end-product method with oral [15N]glycine: comparison of single-dose and intermittentdose regimens. Br. J. Nutr. 74(4): 491-507. PMID:7577888. 
Institute of Medicine. 2002. Dietary reference intakes for energy, carbohydrate, fiber, fat, fatty acids, cholesterol, protein, and amino acids. The National Academies Press, Washington, DC.

Levenhagen, D.K., Carr, C., Carlson, M.G., Maron, D.J., Borel, M.J., and Flakoll, P.J. 2002. Postexercise protein intake enhances whole-body and leg protein accretion in humans. Med. Sci. Sports Exerc. 34(5): 828-837. PMID:11984302.

Levenhagen, D.K., Gresham, J.D., Carlson, M.G., Maron, D.J., Borel, M.J., and Flakoll, P.J. 2001. Postexercise nutrient intake timing in humans is critical to recovery of leg glucose and protein homeostasis. Am. J. Physiol. Endocrinol. Metab. 280(6): E982-993. PMID: 11350780 .

Leverton, R.M., and Gram, M.R. 1949. Nitrogen excretion of women related to the distribution of animal protein in daily meals. J. Nutr. 39(1): 57-65. PMID:18143002.

Mirwald, R.L., Baxter-Jones, A.D.G., Bailey, D.A., and Beunen, G.P. 2002. An assessment of maturity from anthropometric measurements. Med. Sci. Sports Exerc. 34(4): 689-694. PMID:11932580.

Moore, D.R., Areta, J., Coffey, V.G., Stellingwerff, T., Phillips, S.M., Burke, L.M., Cléroux, M., Godin, J.-P., and Hawley, J.A. 2012. Daytime pattern of post-exercise protein intake affects whole-body protein turnover in resistance-trained males. Nutr. Metab. 9(1): 91. doi:10.1186/1743-7075-9-91. PMID:23067428.

Moore, D.R., Robinson, M.J., Fry, J.L., Tang, J.E., Glover, E.I., Wilkinson, S.B., Prior, T., Tarnopolsky, M.A., and Phillips, S.M. 2009. Ingested protein dose response of muscle and albumin protein synthesis after resistance exercise in young men. Am. J. Clin. Nutr. 89(1): 161-168. doi:10.3945/ajen.2008.26401. PMID:19056590.

Moore, D.R., Volterman, K.A., Obeid, J., Offord, E.A., and Timmons, B.W. 2014. Postexercise protein ingestion increases whole body net protein balance in healthy children. J. Appl. Physiol. 117(12): 1493-1501. doi:10.1152/japplphysiol.00224.2014. PMID:25342704.

Obeid, J., Nguyen, T., Walker, R.G., Gillis, L.J., and Timmons, B.W. 2014. Circulating endothelial cells in children: role of fitness, activity, and adiposity. Med. Sci. Sports Exerc. 46(10): 1974-1980. doi:10.1249/MSS.0000000000000313. PMID:24561817.

Rasmussen, B.B., Tipton, K.D., Miller, S.L., Wolf, S.E., and Wolfe, R.R. 2000. An oral essential amino acid-carbohydrate supplement enhances muscle protein anabolism after resistance exercise. J. Appl. Physiol. 88(2): 386-392. PMID:10658002.

Rodriguez, N.R. 2005. Optimal quantity and composition of protein for growing children. J. Am. Coll. Nutr. 24(2): 150S-154S. PMID:15798083.

Schoenfeld, B.J., Aragon, A.A., and Krieger, J.W. 2013. The effect of protein timing on muscle strength and hypertrophy: a meta-analysis. J. Int. Soc. Sports Nutr. 10(1): 53. doi:10.1186/1550-2783-10-53. PMID:24299050.

Thomas, D.T., Erdman, K.A., and Burke, L.M. 2016. American College of Sports Medicine Joint Position Statement. Nutrition and Athletic Performance. Med. Sci. Sports Exerc. 48(3): 543-568. doi:10.1249/MSS.0000000000000852. PMID:26891166.

Timmons, B.W., Tarnopolsky, M.A., Snider, D.P., and Bar-Or, O. 2006. Immunological changes in response to exercise: influence of age, puberty, and gender. Med. Sci. Sports Exerc. 38(2): 293-304. doi:10.1249/01.mss.0000183479.90501.a0. PMID:16531898.

Tipton, K.D., Borsheim, E., Wolf, S.E., Sanford, A.P., and Wolfe, R.R. 2003. Acute response of net muscle protein balance reflects $24-\mathrm{h}$ balance after exercise and amino acid ingestion. 
Am. J. Physiol. Endocrinol. Metab. 284(1): E76-89. doi:10.1152/ajpendo.00234.2002. PMID:12388164.

Tipton, K.D., and Phillips, S.M. 2013. Dietary protein for muscle hypertrophy. Nestle Nutr. Inst. Workshop Ser. 76: 73-84. doi:10.1159/000350259. PMID:23899756.

Tobias, J.H., Steer, C.D., Mattocks, C.G., Riddoch, C., and Ness, A.R. 2007. Habitual levels of physical activity influence bone mass in 11-year-old children from the United Kingdom: findings from a large population-based cohort. J. Bone Miner. Res. 22(1): 101-109. doi:10.1359/jbmr.060913. PMID:17014381.

Tomé, D., and Bos, C. 2000. Dietary protein and nitrogen utilization. J. Nutr. 130(7): 1868S73S. PMID:10867065.

Trost, S.G. 2001. Objective measurement of physical activity in youth: current issues, future directions. Exerc. Sport Sci. Rev. 29(1): 32-36. PMID:11210445.

Volterman, K.A., Moore, D.R., Breithaupt, P., Godin, J.-P., Karagounis, L.G., Offord, E.A., and Timmons, B.W. 2017. Postexercise dietary protein ingestion increases whole body leucine balance in a dose-dependent manner in healthy children. J. Nutr. 147(5): 807-815. doi:10.3945/jn.116.239756. PMID:28381530.

Volterman, K.A., Obeid, J., Wilk, B., and Timmons, B.W. 2014. Effects of postexercise milk consumption on whole body protein balance in youth. J. Appl. Physiol. 117(10): 11651169. doi:10.1152/japplphysiol.01227.2013. PMID:25257865.

Welk, G.J., Corbin, C.B., and Dale, D. 2000. Measurement issues in the assessment of physical activity in children. Res. Q. Exerc. Sport 71(2 Suppl): S59-73. PMID:10925827.

World Health Organization, Food and Agriculture Organization of the United Nations, and United Nations University. 2007. Protein and amino acid requirements in human nutrition. Report of a joint FAO/WHO/UNU expert consultation (WHO Technical Report Series 935). 
Table 1. Macronutrient intake on the exercise intervention day.

\begin{tabular}{llllll}
\hline & Group A & Group B & Group C & Group D & $P$-value \\
& $(n=10)$ & $(n=8)$ & $(n=9)$ & $(n=8)$ & \\
\hline Energy $(\mathrm{kcal})$ & $1961 \pm 404$ & $1883 \pm 325$ & $2053 \pm 303$ & $2076 \pm 475$ & 0.72 \\
Energy $\left(\mathrm{kcal} \cdot \mathrm{kg}^{-1}\right)$ & $43.3 \pm 7.9$ & $44.3 \pm 6.0$ & $41.3 \pm 5.0$ & $42.7 \pm 6.2$ & 0.81 \\
Protein $(\mathrm{g})$ & $38.7 \pm 9.8$ & $37.3 \pm 9.4$ & $43.5 \pm 9.6$ & $43.9 \pm 15.0$ & 0.52 \\
Protein $\left(\mathrm{g} \cdot \mathrm{kg}^{-1}\right)$ & $0.8 \pm 0.1$ & $0.9 \pm 0.1$ & $0.9 \pm 0.1$ & $0.8 \pm 0.2$ & 0.54 \\
CHO $(\mathrm{g})$ & $354.4 \pm 64.6$ & $303.8 \pm 102.3$ & $344.1 \pm 56.7$ & $361.4 \pm 65.6$ & 0.40 \\
CHO $\left(\mathrm{g} \cdot \mathrm{kg}^{-1}\right)$ & $8.0 \pm 1.5$ & $7.2 \pm 2.4$ & $7.1 \pm 0.8$ & $7.5 \pm 1.4$ & 0.66 \\
Fat $(\mathrm{g})$ & $52.2 \pm 17.0$ & $55.4 \pm 17.2$ & $64.8 \pm 8.4$ & $60.3 \pm 21.8$ & 0.39 \\
Fat $\left(\mathrm{g} \cdot \mathrm{kg}^{-1}\right)$ & $1.1 \pm 0.3$ & $1.3 \pm 0.3$ & $1.2 \pm 0.4$ & $1.2 \pm 0.3$ & 0.65 \\
\hline Note: $\mathrm{Valu}$ & & & & & \\
\hline
\end{tabular}

Note: Values are means \pm SD. CHO, carbohydrate. Group A, 0 g + 15 g; Group B, 5 g + 10 g;

Group C, $10 \mathrm{~g}+5 \mathrm{~g}$; Group D, $15 \mathrm{~g}+0 \mathrm{~g}$. 
Table 2. 6-h whole body protein metabolism.

\begin{tabular}{|c|c|c|c|c|}
\hline & $\begin{array}{l}\text { Group A } \\
(n=10)\end{array}$ & $\begin{array}{l}\text { Group B } \\
(n=8)\end{array}$ & $\begin{array}{l}\text { Group C } \\
(n=9)\end{array}$ & $\begin{array}{l}\text { Group D } \\
(n=8)\end{array}$ \\
\hline \multirow{2}{*}{$\mathrm{Q}\left(\mathrm{g} \mathrm{N} \cdot \mathrm{kg}^{-1} \cdot \mathrm{d}^{-1}\right)$} & 0.38 & 0.35 & 0.27 & 0.32 \\
\hline & {$[0.24,1.17]$} & {$[0.22,0.49]$} & {$[0.24,0.32]$} & {$[0.23,0.58]$} \\
\hline \multirow{2}{*}{$\mathrm{S}\left(\mathrm{g} \cdot \mathrm{kg}^{-1} \cdot \mathrm{d}^{-1}\right)$} & 1.99 & 1.82 & 1.31 & 1.56 \\
\hline & {$[1.24,6.92]$} & {$[0.88,2.80]$} & {$[1.17,1.70]$} & {$[1.12,3.19]$} \\
\hline \multirow{2}{*}{$\mathrm{B}\left(\mathrm{g} \cdot \mathrm{kg}^{-1} \cdot \mathrm{d}^{-1}\right)$} & 2.21 & 2.03 & 1.29 & 1.40 \\
\hline & {$[1.25,7.06]$} & {$[0.99,2.77]$} & {$[1.01,1.50]$} & {$[0.85,2.94]$} \\
\hline
\end{tabular}

Note: Values are median [interquartile range]. B, protein breakdown; Q, whole body nitrogen turnover; S, protein synthesis. Group A, $0 \mathrm{~g}+15 \mathrm{~g}$; Group B, $5 \mathrm{~g}+10 \mathrm{~g}$; Group C, $10 \mathrm{~g}+5 \mathrm{~g}$; Group D, $15 \mathrm{~g}+0 \mathrm{~g}$. 
Table 3. 24-h whole body protein metabolism.

\begin{tabular}{lllll}
\hline & Group A & Group B & Group C & Group D \\
& $(n=10)$ & $(n=8)$ & $(n=9)$ & $(n=8)$ \\
\hline $\mathrm{Q}\left(\mathrm{g} \mathrm{N} \cdot \mathrm{kg}^{-1} \cdot \mathrm{d}^{-1}\right)$ & 0.64 & 0.65 & 0.63 & 0.68 \\
& {$[0.57,1.09]$} & {$[0.44,1.48]$} & {$[0.52,0.90]$} & {$[0.52,1.10]$} \\
$\mathrm{S}\left(\mathrm{g} \cdot \mathrm{kg}^{-1} \cdot \mathrm{d}^{-1}\right)$ & 2.79 & 3.07 & 3.39 & 2.74 \\
& {$[2.33,5.17]$} & {$[1.93,8.02]$} & {$[2.16,4.59]$} & {$[2.20,5.14]$} \\
$\mathrm{B}\left(\mathrm{g} \cdot \mathrm{kg}^{-1} \cdot \mathrm{d}^{-1}\right)$ & 2.67 & 2.86 & 2.69 & 3.10 \\
& {$[2.30,5.72]$} & {$[1.44,7.88]$} & {$[2.04,4.43]$} & {$[2.07,5.61]$}
\end{tabular}

Note: Values are median [interquartile range]. B, protein breakdown; Q, whole body nitrogen turnover; S, protein synthesis. Group A, $0 \mathrm{~g}+15 \mathrm{~g}$; Group B, $5 \mathrm{~g}+10 \mathrm{~g}$; Group C, $10 \mathrm{~g}+5 \mathrm{~g}$; Group D, $15 \mathrm{~g}+0 \mathrm{~g}$. 


\section{Figure captions.}

Figure 1. General overview of exercise intervention visit.

Figure 2. Whole body protein balance (WBPB) over $6 \mathrm{~h}$ calculated using the $\left[{ }^{15} \mathrm{~N}\right]$ ammonia endproduct method expressed relative to body mass. Group A $(n=10), 0 \mathrm{~g}+15 \mathrm{~g}$; Group B $(n=8)$, $5 \mathrm{~g}+10 \mathrm{~g}$; Group C $(n=9), 10 \mathrm{~g}+5 \mathrm{~g}$; Group D $(n=8), 15 \mathrm{~g}+0 \mathrm{~g}$. Boxplot demonstrates median value and interquartile range, with whiskers demonstrating minimum and maximum values. *, Significant difference from zero $(P<0.05)$. $†$, Trend for significance from zero $(P=$ 0.09). The solid line demonstrates the predictive values analyzed by robust regression. The small open circles represent outlying data points.

Figure 3. Whole body protein balance (WBPB) over $24 \mathrm{~h}$ calculated using the harmonic mean of $\left[{ }^{15} \mathrm{~N}\right]$ ammonia and $\left[{ }^{15} \mathrm{~N}\right]$ urea expressed relative to body mass. Group A $(n=10), 0 \mathrm{~g}+15 \mathrm{~g}$; Group B $(n=8), 5 \mathrm{~g}+10 \mathrm{~g}$; Group C $(n=9), 10 \mathrm{~g}+5 \mathrm{~g}$; Group D $(n=8), 15 \mathrm{~g}+0 \mathrm{~g}$. Boxplot demonstrates median value and interquartile range, with whiskers demonstrating minimum and maximum values. \#, Trend for significant difference from zero when outlier removed $(P=0.06)$. The solid line demonstrates the predicted values modeled by an orthogonal polynom of the second order analyzed by robust regression. The small open circles represent outlying data points. 


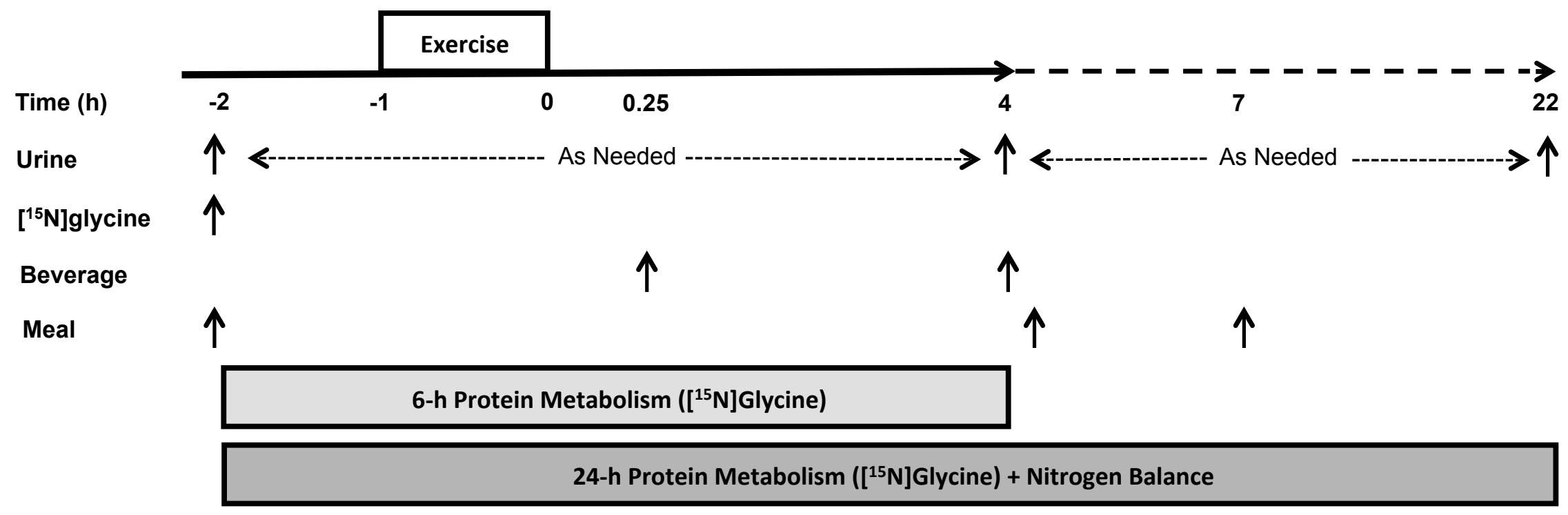




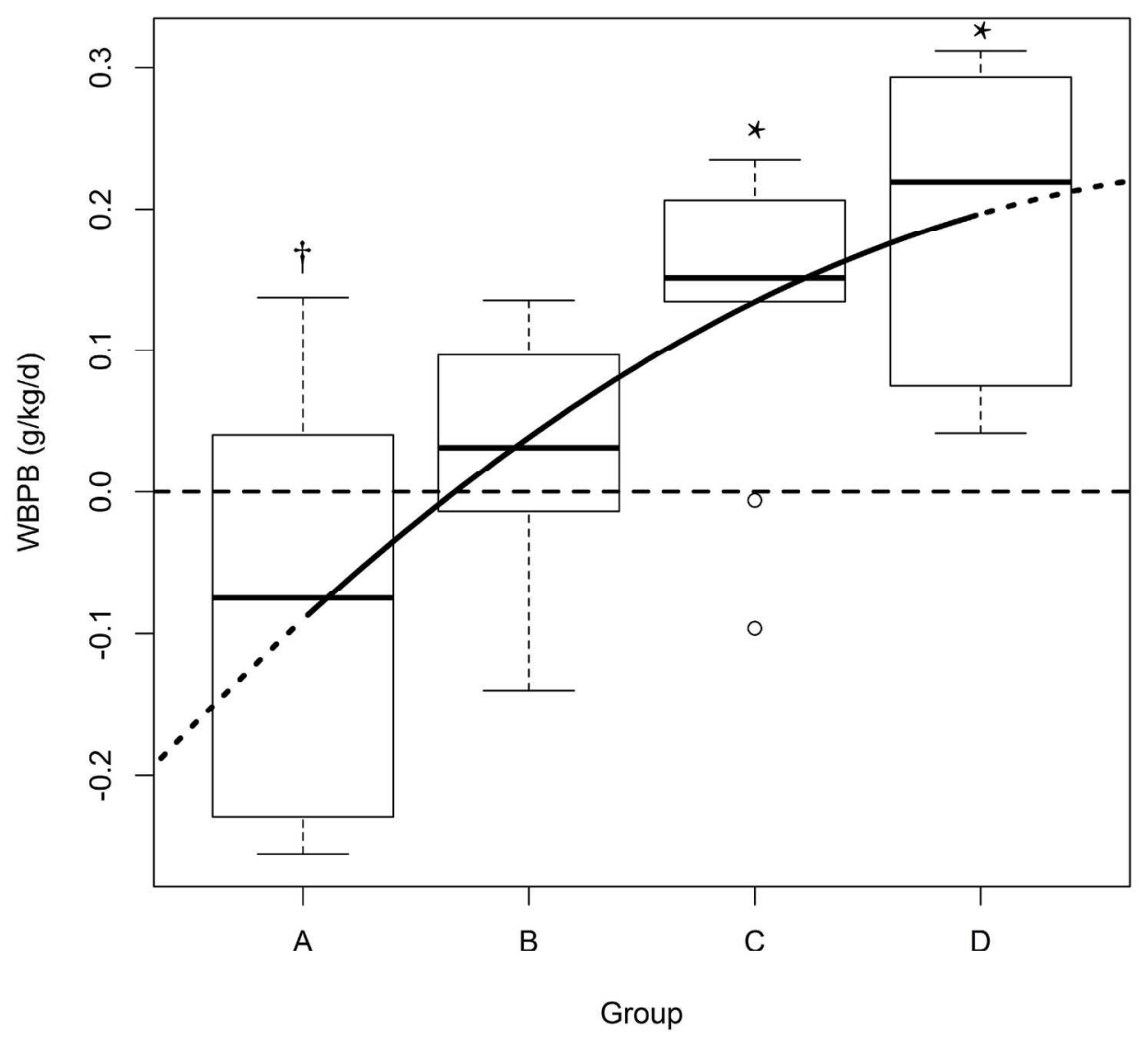

Figure 2

$169 \times 169 \mathrm{~mm}(300 \times 300$ DPI $)$ 


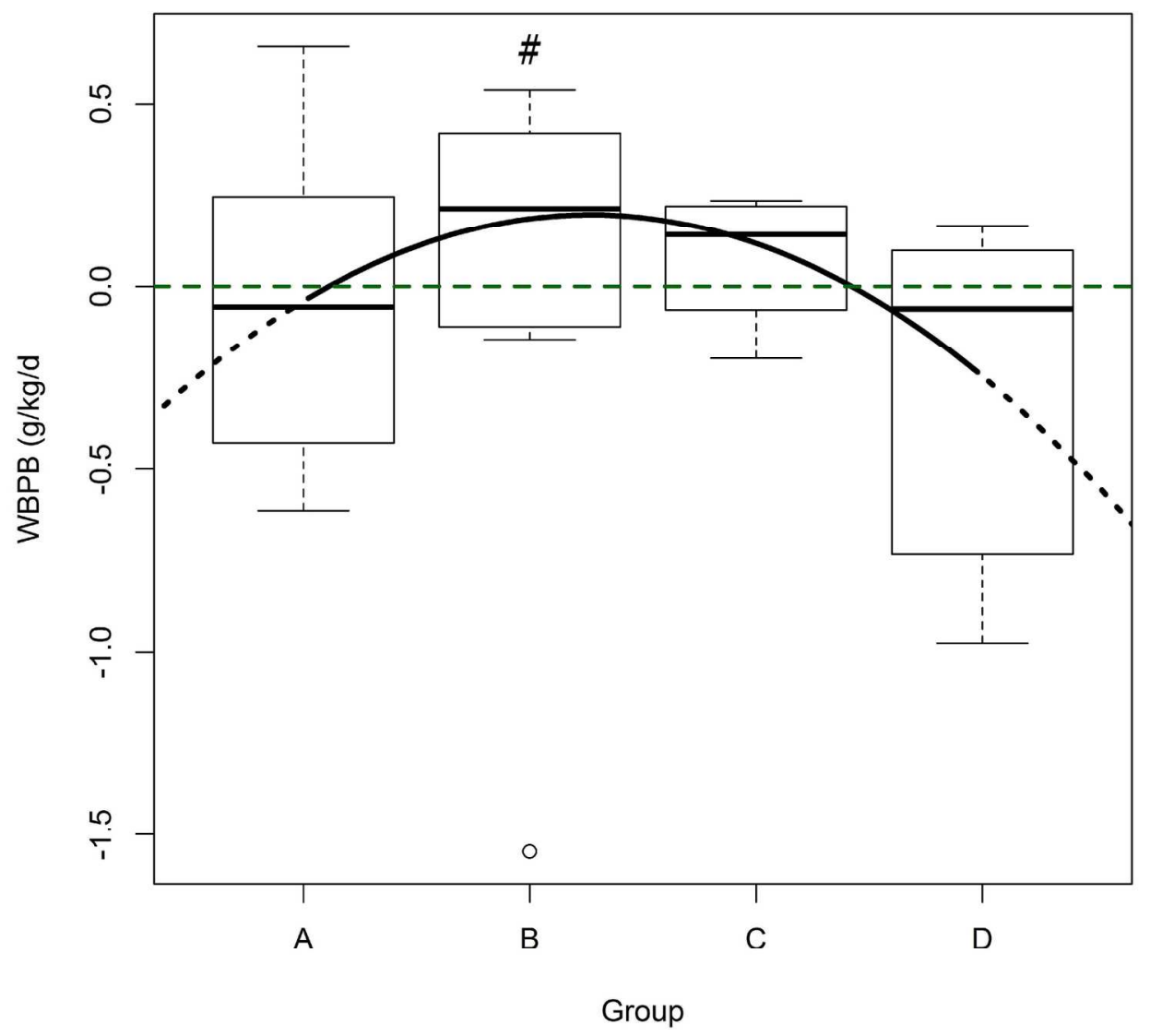

Figure 3

$169 \times 169 \mathrm{~mm}(300 \times 300$ DPI $)$ 